STUDIA EDUKACYJNE NR 31/2014

\author{
DARIUSZ P. SKOWROŃSKI ${ }^{1}$, DANIEL JUSTIN FONG TAY², \\ MICHELLE HO WEN WAN², TOH SHI YING CHERIE², \\ TRICIA MARJORIE FERNANDEZ2, KATARZYNA WASZYŃSKA ${ }^{3}$ \\ ${ }^{1}$ Temple University Japan Campus, Tokyo \\ ${ }^{2}$ Temasek Polytechnic, Singapore \\ ${ }^{3}$ Adam Mickiewicz University, Poznań
}

\title{
THE COMPARISON OF MARITAL AND FAMILY FACTORS BETWEEN SINGAPOREAN MONOCULTURAL AND INTERCULTURAL COUPLES
}

\begin{abstract}
Skowroński Dariusz P., Fong Tay Daniel Justin, Ho Wen Wan Michelle, Ying Cherie Toh Shi, Fernandez Tricia Marjorie, Waszyńska Katarzyna, The Comparison of Marital and Family Factors Between Singaporean Monocultural and Intercultural Couples [Analiza porównawcza czynników małżeńskich i rodzinnych $\mathrm{w}$ związkach mono- i międzykulturowych $\mathrm{w}$ Singapurze]. Studia Edukacyjne nr 31, 2014, Poznań 2014, pp. 249-266. Adam Mickiewicz University Press. ISBN 978-83232-2781-6. ISSN 1233-6688

The number of intercultural marriages in Singapore has recently been on the rise and research has found that these mixed marriages and relationships tend to have lower levels of marital satisfaction in comparison to monocultural marriages. To determine whether the level of marital satisfaction will be higher for monocultural couples as compared to intercultural couples, a 40-item questionnaire and an 8-item interview was developed based on 8 different factors of couple dynamics and family factors. 10 monocultural couples and 11 intercultural couples were recruited to complete the questionnaire and five monocultural couples, and five intercultural couples from this participant pool participated in an additional interview. It was hypothesized that the marital satisfaction scores, based on both couple dynamics and family factors, will be higher in monocultural couples as compared to intercultural couples. Contrary to that, results showed that intercultural couples demonstrated higher marital satisfaction scores as compared to monocultural couples. Arguably, it may be possible that Singapore and the other parts of the world might differ by having a strong foundation of interethnic ties, which may have made intercultural marriages more widely accepted.
\end{abstract}

Key words: intercultural marriages, marital factors, family factors, marital satisfaction

\section{Introduction}

The available data in Singapore strongly support the observation that the phenomenon of international marriage, as reflected in the Figures from 
Population in Brief 2010, shows the trend continues to strengthen steadily. According to the Yearbook of Statistics Singapore, the intercultural marriages have risen from 1761 marriages in the year of 2000 to 3550 marriages in the year of $2010.1^{1} 16.4$ per cent of a total about 24,000 marriages in 2007 were intercultural marriages compared to 8.9 per cent about ten years ago', and the estimate of the number of non-citizen spouses married to Singapore citizens is 8,848 in $2009 .^{3}$

It is also foreseen for the upcoming 50 years, that it is very likely that international marriages will continue to rise across cultures. ${ }^{4}$ However, relationships among partners from the different cultural backgrounds are found to have a higher risk for failure, accounting stressful conditions, ending up in divorce, or experiencing lower marital satisfaction rate, as compared to monocultural couples. Intercultural couples seem to have additional sources of difficulties, unlike monocultural couples which include macrocultural factors found in the family and society, and microcultural factors in the varying couple dynamics. ${ }^{5}$

\section{Monocultural and Intercultural couples}

Intercultural marriages might face a different set of couple dynamics and family factors as compared to monocultural couples due to their cultural differences. However, both monocultural and intercultural couples aim for mutual accommodation, and they also both share the basic needs for affection, support, trust, and respect from one another. ${ }^{6}$ Both monocultural and intercultural couples also undergo other similar challenges such as adjustment to marriage, personality differences, and being caregivers to their own parents. ${ }^{7}$ Additionally, Gaines et al. ${ }^{8}$, state that insecurely attached individu-

1 Yearbook of Statistics Singapore, 2011.

2 D.W. Tan, No mixed feelings over mixed marriages, "The Straits Times", 2010, January 31.

${ }^{3}$ National Population Secretariat, Singapore Department of Statistics, Ministry of Community Development, Ministry of Home Affairs, and Authority 2010.

${ }^{4}$ M.W. Frame, The challenges of intercultural marriage: Strategies for pastoral care, Pastoral Psychology, 2004, 52 (3), p. 219-232. Retrieved from: http://scholar.google.com.sg.

${ }^{5}$ D. Bhugra, P. De Silva, Couple therapy across cultures, Sexual and Relationship Therapy, 2000, 15, p. 183-192.

${ }^{6}$ C.J. Falicov, Cross-cultural marriages, [in:] Clinical handbook of couple therapy, eds N. Jacobson, A. Gurman, New York 1995, p. 231-246.

7 S. Donovan, Stress and coping techniques in successful intercultural marriages - unpublished master's thesis, Faculty of the Virginia Polytechnic Institute and State University, 2004.

8 S.O. Gaines et al., Patterns of attachment and responses to accommodative dilemmas among interethnic/interracial couples, Journal of Social and Personal Relationships, 1999, 16, p. 277-287. 
als tend to reciprocate their partners' anger or criticism that is also a longterm threat to the relationship stability.

Similarly, the Social Exchange Theory can be used to understand the similarities between monocultural and intercultural couples. The Social Exchange Theory is often used to explain dynamics of interactions between individuals. ${ }^{9}$ The romantic relationships are based the valuable exchange of a give-and-take system of commodities. In the context of relationships, the commodities being exchanged were the male's financial security and the female's physical attractiveness ${ }^{10}$ which is traditionally fundamental in both monocultural and intercultural couples. There also has been recent interracial literature proposing that interracial couples date and marry for the same reasons as same-race couples, such as mutual interests. ${ }^{11}$

As seen in the study done by Carrasco ${ }^{12}$, participants rated the same-race and interracial couples similarly on variables measuring general relationship dynamics. There were no significant differences between same-race and interracial couples when participants rated the degree to which the male respected the female and vice versa, how controlling the male or the female was with his or her partner, how submissive the male or the female was with his or her partner, and how jealous the male or the female became when his or her partner interacted with other males or females.

\section{Purpose of research}

The aforementioned research about the many different issues of couple dynamics and family factors are essential in maintaining a satisfying marital relationship. However, in the literature of intercultural couples, not many of these factors were done in comparison to monocultural couples and were mostly completed in the context of the United States. Nevertheless, there is

${ }^{9}$ P.M. Blau, Exchange and power in social life, New York 1967.

10 T.B. Heaton, S.L. Albrecht, The changing pattern of interracial marriage, Social Biology, 1996, 43, p. 203-217.

11 R. Lewis Jr., G. Yancey, S.S. Bletzer, Racial and nonracial factors that influence spouse choice in Black/White marriages, Journal of Black Studies, 1997, 28, p. 60-78; K. Shibazaki, K.A. Brennan, When birds of different feathers flock together: A preliminary comparison of intra-ethnic and interethnic dating relationships, Journal of Social and Personal Relationships, 1998, 15, p. 248-256; G.A. Yancey, S.W. Yancey, Black-White differences in the use of personal advertisements for individuals seeking interracial relationships, Journal of Black Studies, 1997, 27, p. 650-667; G.A. Yancey, S.W. Yancey, Interracial dating: Evidence from personal advertisements, Journal of Family Issues, 1998, 19, p. 334-348.

12 G. Carrasco, Perceptions of same-race and interracial dating couples on sexuality and relationship variables - doctorate dissertation, Texas Tech University, Texas 2007. 
also a rise of intercultural marriages in Southeast Asia in recent years. Due to the limited literature based on the Singaporean context, there should be further investigation on the psychological phenomena of such marriages in Singapore, and comparisons with monocultural couples should be made.

It is, therefore, hypothesised that marital satisfaction scores based on both couple dynamics and family factors will be higher for monocultural couples as compared to intercultural couples. This is because interracial couples are commonly perceived as more likely to fail in a relationship, as less compatible, as less attractive, and as less likely to gain approval than monocultural couples. ${ }^{13}$ Moreover, the family factors seem to be more prevalent problems for intercultural couples in comparison to monocultural couples.

\section{Participants}

The sample of the pilot study consisted of 10 monocultural heterosexually married couples, and 11 intercultural heterosexually married couples. There were a total of 21 females and 21 males. The participants were recruited for this study via convenience sampling. The criteria selected for intercultural couples were: (1) A Westerner who is from either Europe, North America or Australia, married to a Singaporean man or woman for at least 3 years similar to the study done by Jabar ${ }^{14}$ to ensure that the marriage is stable and ongoing; (2) The couple must be raising at least one child together15; (3) The couple must reside together in Singapore to understand, how the couple functions in the context of the Singaporean culture.

The criteria selected for monocultural couples were: (1) a couple consisting of both Singaporean nationalities, regardless of race, and married for at least 3 years; (2) The couple must be raising at least one child together. (3) The couple must reside in Singapore. There was no limit to the age of the participants or the age gap within a married couple between both the intercultural and monocultural couples.

${ }^{13}$ S.D. Garcia, S.M. Rivera, Perceptions of Hispanic and African-American couples at the friendship or engagement stage of a relationship, Journal of Social and Personal Relationships, 1999, 16, p. 65-86.

${ }^{14}$ M.A. Jabar, Backgrounds of marriage: Conflict experiences of Filipino wives in intercultural marriages, Graduate Journal of Social Science, 2006, 3 (2), p. 43-57.

${ }_{15}$ M. Forna, Differences that get under the skin: Race problems between black skinned people of different origins, "The Guardian", 1992, July, p. 19-20; R.L. Hegar, G.L. Greif, Parental abduction of children from interracial and cross-cultural marriages, Journal of Comparative Family Studies, 1994, 25, p. 135-138. 


\section{Method}

The team of researchers developed a questionnaire consisting of a total of 40 questions based on the aforementioned factors of couple dynamics and family factors and how they affect marital satisfaction. There were five questions related to marital satisfaction for each of the factors of couple dynamics (i.e. language and communication, the cultural stereotype, child rearing, and financial issues), as well as for each of the factors of family factors (i.e. societal views, social support, family, and religion). A 5-point Likert scale was used to investigate the questions. Participants completed the questionnaire individually.

In addition to the questionnaire, the team conducted interviews on five intercultural couples and five monocultural couples taken from the pool of 21 couples. The interview script consisted of eight open-ended questions regarding the factors of couple dynamics and family factors, and how they affect marital satisfaction.

\section{Procedure}

There were two different procedures in this pilot study. Before the start of the study, all participants were given an informed consent form to fill up. The couples went through either the first or second procedure based on random assignment.

In the first procedure (P1), five intercultural couples (I1-I5) and five monocultural couples (M1-M5) were briefed on what the study was about. They were then given a questionnaire that took up to 30 minutes to complete. The questionnaires were completed individually. After that, the participants were debriefed.

In the second procedure (P2), the other 5 intercultural couples (I6-I10) and the other 5 monocultural couples (M6-10) were briefed on what the study was about. They were then interviewed by the researchers, and this process lasted for up to an hour. The entire session of each interview was voice recorded. After the interview, they were given the same questionnaires that were given out in the first procedure, which took about 30 minutes to complete. These questionnaires were completed individually. Upon completion of the questionnaire, the participants were then debriefed.

\section{Results}

Qualitative Analysis. The first question of the interview portrayed the factor of language and communication in couple dynamics. 
All the couples used a common language at home which is English; thus they did not experience language barrier problems. There was one intercultural couple consisting of a Canadian husband and a Singaporean wife that pointed out the differences in language when it came to the meaning of some words. In the Canadian culture, "dinner" is a term for the afternoon meal and "supper" is the term used for the evening meal. However, in Singapore, "lunch" is a term used for the afternoon meal, and "dinner" is the term for the evening meal. This was simply a minor difference in communication, hence; it did not impact their marriage.

Another intercultural couple noted different communicating styles that were influenced by one's culture. The Westerner spouse pointed out that there was an "Asian way and the European way of communicating", but by adopting each other's style of communication, they were able to "get to a point". They also mentioned that they would discuss any issues while communicating if they were to come across any.

The second question addressed the cultural stereotypes that may lead to different expectations of one another in an intercultural marriage. The results obtained show that both monocultural and intercultural couples had positive responses.

Most of the intercultural couples did not produce any cultural stereotypes or expectations of their spouses. However, there was a Chinese wife of an intercultural couple who mentioned that her expectations of a Westerner husband were shaped by television shows before she married him. After getting married and getting to know her husband's family, she found out that his family was "as traditional as hers" as they shared similar values on marriage, child rearing, and being responsible, thus being quite different from what was depicted on television.

The third question which addressed child rearing issues obtained results showing that all monocultural couples had positive responses, $80 \%$ of the intercultural couples had positive responses, whereas $20 \%$ of them had negative responses.

All the monocultural couples were able to work out the issues regarding child rearing. For example, one of the couples indicated that their disciplinary approaches depended on their child's character.

One of the intercultural couples commented that they "tried to get the good parts" of both of their cultures passed down to their children, hence; they "grew up with the best practices of both cultures". The husband also realised many similarities between both of their cultures, such as respecting the elderly, table manners, greetings, etc. 
The Westerner husband of another intercultural couple preferred Asian values being passed down to their children as it is "a lot more guided" as compared to Western values.

Another intercultural couple had different styles in raising their children, hence; resulting in a negative response in the interview. The Singaporean wife is more of a disciplinarian and accepts the caning due to her educational background. However, the Westerner husband does not believe in this as he had a "stress-free educational background". Corporal punishment is frowned upon in his culture and importance is placed on whether the child is happy or not, which led to him conclude that he was unfamiliar with the Singaporean method of disciplining children.

The fourth question talked about handling financial issues as a couple, and the results obtained portrayed that $100 \%$ of both the monocultural and intercultural couples shared positive responses.

All the monocultural couples had discussions regarding major expenses before making any decisions. Additionally, one couple added that the husband is in charge of the major expenses as he is the sole breadwinner of the family.

All the intercultural couples had no significant differences when it came to handling financial matters and did not have different perspectives on the value of money. Similarly, two intercultural couples mentioned that their husbands are in charge of the major expenses as they are the sole breadwinners.

The fifth question referred to societal views the couple received. All both monocultural and intercultural couples indicated positive responses.

None of the monocultural couples received judgmental looks or insensitive comments from the public or in the workplace as the couples are of the same culture.

Similarly, none of the intercultural couples commented on receiving negative comments from the public regarding their relationship as they felt that intercultural marriages are "quite common in Singapore". One of the intercultural couples commented that most of their colleagues are in mixed marriages; thus there were no such problems in the workplace. Additionally, the couple commented that only their kids "get judgmental looks because they obviously look different" from the rest of the children at school.

The sixth question of the interview regarded the social support received by friends, shows that $100 \%$ of both monocultural and intercultural expressed positive responses.

All of the monocultural couples said that their friends accepted and supported their relationship and their marriage with each other. One couple 
also mentioned that they had common social networks and their friends "had known each of them for a long time".

Four intercultural couples mentioned that most of their friends were also in intercultural marriages, so there were no problems with regards to social support. The Singaporean wife of one of the couples commented that she only had "surprised reactions from friends as they see her as being very Chinese and Asian" thus being very traditional. She then went on to explain that in her generation, "those who marry Coucasians are Sarong Party Girls (SPG) and very wild". However, her friends saw her as "being very square and boring", hence; they had more of a surprised reaction but not a negative one.

The seventh question asked about how their families reacted to the couple's relationship. The results show that $80 \%$ of both monocultural and intercultural couples had positive responses while $20 \%$ of both of these couples had negative responses.

Almost all the monocultural couples said that their families accepted their marriage except for one couple whereby the husband's siblings frowned upon the relationship due to the wife belonging to different racial background.

The parents of four of the intercultural couples did not oppose the relationship, and one of the reasons was because their children got married in their late thirties. However, in one of the intercultural couples, the Singaporean wife mentioned that her father opposed the relationship as he was a "traditional Chinese" and also because the couple was living together before getting married.

The eighth question focused on religion and based on the results $100 \%$ of intercultural couples had positive responses while $60 \%$ of the monocultural couples had positive responses, and $40 \%$ of them had neutral responses.

One of the monocultural couples was not particular about religion and another couple had the same religion as each other. For another, the wife who had a different religion voluntarily converted to the husband's religion. Two other couples responded in a neutral manner as they commented that "they have not really considered this issue before in the marriage", hence; they did not take a stand on religion.

Most of the intercultural couples had no problems dealing with religious issues as they belonged to the same religious groups. As for two of the intercultural couples, although the spouses had different religions with each other, it "did not bother them" as they were not very strong practitioners of their own separate religions to begin with. Additionally, for one of those couples, the Westerner husband is respectful when he attends Buddhist rites 
or funerals at the temple with his wife's family. Therefore, there was "nothing to fight or argue about" when it came to the topic of religion.

After reviewing all of the comments made by the couples, it can be seen that both the samples of intercultural couples and monocultural couples did not have major issues with regards to the factors of couple dynamics as well as family factors affecting their marital satisfaction levels. The qualitative results will be further interpreted in the discussion section of the study.

\section{Quantitative Analysis}

Independent sample t-tests were used to analyse the results of each item in the questionnaires by assessing if the mean scores of the monocultural couples are significantly different from the mean scores of intercultural couples.

An independent sample t-test of the means showed that a significant difference was detected and out of 40 items, 12 of them were shown to be of statistical significance. A more detailed analysis is shown below.

It was found that marital satisfaction in terms of the ability to understand what was meant to be serious or not, was significantly higher $(t=3.03$, $\mathrm{DF}=40, \mathrm{p}=0.004)$ for intercultural couples $(\mathrm{M}=3.73)$ than in monoculutral couples $(\mathrm{M}=2.55)$.

Marital satisfaction was also shown to be significantly higher $(t=2.36$, $\mathrm{DF}=40, \mathrm{p}=0.023)$ for intercultural couples $(\mathrm{M}=4.64)$ as compared to monocultural couples $(\mathrm{M}=4.20)$, with lower levels of frustration during arguments because of the language use.

Monocultural couples $(\mathrm{M}=3.50)$ showed significantly higher $(t=5.06$, $\mathrm{DF}=40, \mathrm{p}<0.001)$ marital satisfaction in terms of the cultural expectations of one's spouse in comparison with the intercultural couples $(\mathrm{M}=1.77)$.

Intercultural couples $(\mathrm{M}=4.91)$ were less fearful of judgemental looks when they were together in public, thus showing significantly higher $(\mathrm{t}=3.95, \mathrm{DF}=21.71, \mathrm{p}=0.001)$ marital satisfaction than monocultural couples $(\mathrm{M}=3.95)$.

Intercultural couples $(\mathrm{M}=4.68)$ also felt that the society does not look down on them due to their marriage to a significantly greater extent $(\mathrm{t}=2.33, \mathrm{DF}=40, \mathrm{p}=0.025)$ as compared to monocultural couples $(\mathrm{M}=4.20)$, yielding higher marital satisfaction levels.

It was found that marital satisfaction was significantly higher $(t=2.46$, $\mathrm{DF}=40, \mathrm{p}=0.018)$ for intercultural couples $(\mathrm{M}=4.68)$ as compared to monocultural couples $(\mathrm{M}=4.05)$ in terms of the insensitive comments that others made about their marriage. 
Intercultural couples $(\mathrm{M}=3.55)$ showed significantly higher levels of marital satisfaction $(t=2.82, \mathrm{DF}=40, \mathrm{p}=0.008)$ in terms of the ability to handle the relationship better when there is social support as compared to monocultural couples $(\mathrm{M}=2.55)$.

Intercultural couples $(\mathrm{M}=4.45)$ were found to have a significantly higher $(t=2.34, D F=40, p=0.024)$ marital satisfaction with a lesser chance of having their family members expressing concern about their marriage as compared to monocultural couples $(\mathrm{M}=3.70)$.

It was found marital satisfaction was significantly higher $(t=3.42$, $\mathrm{DF}=40, \mathrm{p}=0.001)$ for intercultural couples $(\mathrm{M}=4.59)$ as compared to monocultural couples $(\mathrm{M}=3.85)$ in consideration of their families' attitudes towards them after marriage.

Intercultural couples $(\mathrm{M}=3.23)$ were lower in marital satisfaction in terms of having a significantly higher $(t=3.00, \mathrm{DF}=31.76, \mathrm{p}=0.006)$ chance of severing ties with one's family than in monocultural couples $(\mathrm{M}=4.25)$.

Marital satisfaction based on the ability of couples to resolve difficulties in religious and/or spiritual beliefs was significantly higher $(t=6.23$, $\mathrm{DF}=40, \mathrm{p}<0.001)$ for monoculutral couples $(\mathrm{M}=4.10)$ than in intercultural couples $(\mathrm{M}=2.45)$.

It was found marital satisfaction was significantly higher $(t=3.38$, $\mathrm{DF}=40, \mathrm{p}=0.002)$ in monocultural couples $(\mathrm{M}=3.85)$ than in intercultural couples $(\mathrm{M}=2.95)$ in terms of having a spouse of the same religion and/or personal beliefs, hence; providing them with a sense of security.

\section{Discussion}

In summary, the research team developed a 40-item questionnaire as a measurement tool to assess the different levels of marital satisfaction between monocultural and intercultural couples based on four factors of couple dynamics (i.e. language and communication, the cultural stereotypes, child rearing, and financial issues) and four family factors (i.e. societal views, social support, family, and religion).

It was shown that the findings generated from the questionnaire and interviews, did not fully support the hypothesis, whereby marital satisfaction scores for monocultural couples would be higher than intercultural couples. Instead, it was found that monocultural couples and intercultural couples had significantly higher scores in different items of the questionnaire. 
Based on the questionnaire that was administered to the participants, the team found that monocultural couples scored significantly higher than intercultural couples on one item of couple dynamics (i.e. cultural stereotypes), and two items of family factors (i.e. family and religion). On the other hand, intercultural couples scored significantly higher on two items of couple dynamics (i.e. language and communication), and six items of family factors (i.e. societal views, social support, and family).

\section{Language and Communication}

Communication in marriage is a key factor in maintaining martial satisfaction. ${ }^{16}$ A study from Sechrest, Fay, and Zaidi ${ }^{17}$ has shown many ways on how intercultural couples will have more difficult time communicating with each other as compared to monocultural couples. However, the results showed that intercultural couples have "no problems" with communication and language, and were able to overcome problems through proper discussions with each other. This might be due to the fact that Singapore adopts English as a first language, which is the same native language as many westerner participants. Hence; these Singaporean spouses might have an easier time communicating with their Western spouses who would also be highly likely to speak English as compared to a Filipino spouse who may not know how to speak English when communicating with a White spouse. ${ }^{18}$

\section{Cultural Stereotypes}

In any marriage, there are specific roles that each spouse will play. This study found that monocultural couples tend to have fewer problems than intercultural couples when it comes to stereotyping their spouse. Similarly, an example of a cultural stereotype can be found in a study by Taweekua-

16 L. Kitivipart, Communication and interaction styles in Thai-American cross-cultural marriage, Ph.D. Dissertation in Psychology, International University, School of Human Behaviour, San Diego 1987.

17 L. Sechrest, T.L. Fay, S.M. Zaidi, Problem of translation in cross-cultural communication, [in:] Intercultural Communication: A Reader (5th edition), eds L.A. Samovar, R.E. Porter, Belmont CA 1988, p. 253-262.

18 M.A. Jabar, Backgrounds of marriage, p. 43-57. 
kulkit $^{19}$ whereby a North American's idea of Southeast Asia women was reinforced by mass media that often stereotyped Asians as being quiet or submissive.

The Singaporean spouse of an intercultural couple had expectations of her Westerner spouse that were shaped by "television programmes", thus having cultural expectations of her spouse in the beginning. However, the Singaporean spouse gradually realised that these stereotypes were distorted and not applicable as the Westerner spouse's family was "as traditional as hers" and they had similar personal values on marriage, child rearing, etc. From an interview, it was evident that these stereotypes could be misrepresentative and even distorted in reality. Thus, cultural expectations might cause unnecessary pressure to the couple, and might, hence; lead to a lower level of marital satisfaction if not appropriately adjusted or resolved.

\section{Societal Views}

The society often judges intercultural couples, putting pressure on these couples who might, therefore, choose not to appear to be together in public. ${ }^{20}$ However, from this study, the results showed that intercultural couples scored a significantly higher level of marital satisfaction on a total of three items that were based on the factor of societal views.

The couples did not seem to be fearful of judgemental looks in public, and they did not seem to feel that the Singaporean society looked down on them. Additionally, they received almost no comments that were insensitive to their marriage from work and social settings. From an interview, one of the couples responded that "not in Singapore, quite common to see intercultural couples in Singapore" when asked about this issue.

Furthermore, one of the couples noted that they received "more positive comments" instead. This suggests that intercultural marriages are common in Singapore's context, and it is widely accepted locally. On the other hand, Singapore is a multiracial and multicultural nation as compared to the United States whereby La Taillade ${ }^{21}$ states that the racial discrimination is

${ }_{19}$ N. Taweekuakulkit, Thai-North American intercultural marriage in the U.S.: A qualitative study of conflict from Thai wives' perspectives - Master's thesis, Wayne State University 2005, Dissertation Abstracts International, Volume: 66-11, Section: A, page: 3866.

${ }^{20}$ C.L. Crippen, Working with intercultural couples and families: Exploring cultural dissonance to identify transformative opportunities, 2011. Retrieved from http://counselingoutfitters.com/ vistas/vistas11/ Article_21.pdf.

${ }^{21}$ J.J. La Taillade, Predictors of satisfaction and resiliency in African American/White interracial relationships - unpublished doctoral dissertation, University of Washington, Seattle 1999. 
still a common stressor to intercultural or interracial couples. Therefore, one of the reasons behind the results contradicting the literature might be due to the differences in context (i.e. United States, Singapore).

\section{Social Support}

The amount of social support a couple received was found to be positively correlated with their level of marital satisfaction ${ }^{22}$, which is consistent with our obtained results. This study showed that the intercultural couples portrayed significantly higher levels of marital satisfaction than monocultural couples based on their ability to manage the relationship better with the presence of social support.

Monocultural couples usually said that their friends "accepted" and "supported" the marriages. This showed that monocultural couples may not value social support as much as intercultural couples in terms of the importance of helping them manage their relationship better.

On the other hand, intercultural couples had most of their friends in mixed marriages, and friends who accepted them without classifying them as Asians and non-Asians. Hence; intercultural couples often had supportive friends, which enabled them to handle their relationship better.

Albrecht and Adelman ${ }^{23}$ found that the social support decreases anxiety and stress of intercultural marriages. This study offered the chance to help the society understand that intercultural couples could handle their relationship better with the support of their friends, whereas social support might not be a significant area of concern in a monocultural marriage.

\section{Family members}

The factors concerning family are broad, and have many different aspects (i.e. family ties, family support) to it; in this study, both monocultural and intercultural couples scored higher in these different areas.

In the first aspect, intercultural couples indicated that they were more likely to sever family ties as compared to monocultural couples. Monocul-

22 C. Shute, B. Spitzberg, Intercultural couples: examining the role of social support, A paper presented to the Hawaii International Conference on Social Sciences, June 12-15, 2003.

${ }^{23}$ T.L. Albrecht, M.B. Adelman, Communicating social support: A theoretical perspective, [in:] Communicating Social Support, eds T.L. Albrecht, M.B. Adelman, Newbury Park, CA 1987, p. 18-39. 
tural couples who went through the interview said that they received great family support and acceptance. On the other hand, there was an intercultural couple who faced an opposing parental view, as the Singaporean spouse's father was an "old-fashioned Chinese". Furthermore, some spouses of the intercultural couples may have "lived away" from the family for many years, thus receiving little family contact or support. Kouri and Lasswell24 stated that most families do not show acceptance towards intercultural marriages, which may have driven intercultural couples to the point of severing family ties to keep the relationship going. ${ }^{25}$ Therefore, intercultural couples are more susceptible to the problem, and this might lead to resentment of the spouse if family ties were severed, thus having a lower marital satisfaction level.

In the other aspect of family (i.e. family support), intercultural couples scored higher levels of marital satisfaction as compared to monocultural couples with regards to the concerns and attitudes expressed by family members towards the couple after marriage. This meant that intercultural couples do have a higher rate of support from their family, which is contradictory to the numerous studies done by Davidson and Schneider ${ }^{26}$, Mills, Daly, Longmore, and Kilbride ${ }^{27}$, and Faulkner and Kich ${ }^{28}$ who suggested that most of the families of intercultural couples most likely show disagreements or concerns over such a marriage to a certain degree or extent.

Again, a possible explanation of this phenomenon might be because of the context of this study; Singapore's multi-ethnic and multiracial society allows the families of intercultural couples to be more open to intercultural marriages, as compared to the culture in the United States which shows more racial and cultural intolerance in their society ${ }^{29}$. Additionally, it could also be due to the sample of this study whereby the couples commented during the interview that they got married in their late thirties, hence; leading their families to accept their relationship.

${ }^{24}$ K.M. Kouri, M. Lasswell, Black-White marriages: Social change and intergenerational mobility, Marriage \& Family Review, 1993, 19, p. 241-255.

25 B.L. Sung, Chinese American intermarriage, Journal of Comparative Family Studies, 1990, 21, p. 337-353.

26 J.R. Davidson, L.J. Schneider, Acceptance of Black-White interracial marriage, The Journal of Intergroup Relations, 1992, 19 (3), p. 47-52.

27 J.K. Mills et al., A note on family acceptance involving interracial friendships and romantic relationships, Journal of Psychology, 1995, 129, p. 349-351.

28 J. Faulkner, G.K. Kich, Assessment and engagement stages in therapy with the interracial family, [in:] Cultural perspectives in family therapy, ed. C.J. Falicov, Rockville Md. 1983, p. 79-90.

${ }^{29}$ K.D. Killian, Crossing borders: Race, gender, and their intersections in interracial couples, Journal of Feminist Family Therapy, 2001, 13, 1. 


\section{Religion}

The results of this study showed that most of the participants who were in monocultural marriages are married to spouses of the same religion and/or personal beliefs, thus providing them with a sense of security which could lead to a higher level of marital satisfaction. ${ }^{30}$ Additionally, the results showed that monocultural couples were likely to resolve difficulties in religious or spiritual beliefs.

This was supported by the findings of Frame ${ }^{31}$, which stated that most intercultural couples represented different backgrounds and are highly likely to have different religious beliefs as compared to monocultural couples. Having different religious beliefs could also affect their lifestyles such as which cultural traditions to follow, and the philosophy of raising a child. Therefore, this could lead to disagreements within the marriage, hence; leading the intercultural couples to have a lower personal sense of security as they might not feel supported by their spouse regarding their religious and/or personal beliefs.

On the other hand, no major issues or disagreements arose due to religious and/or personal beliefs for any of the intercultural couples that were interviewed. This was because most of them managed to reach a compromise (i.e. converting to their spouse's religion, not letting religion affect their marriage, being non-religious or non-practitioners of their own separate religions) in this area. Many of them also commented that they did not let religion affect the way of how they raised their children and would let them decide which religious groups that they would like to belong to when they are older.

\section{Non-Significant Factors}

Child Rearing. Differing parenting styles often poses as an issue in intercultural marriages. ${ }^{32}$ Although no significant differences were found in the questionnaire regarding child rearing issues in both intercultural and monocultural couples, one of the couples stated in the interview that both of them had conflicting and contrasting parenting styles because of the different cultures that they were brought up in.

\footnotetext{
${ }^{30}$ S. Donovan, Stress and coping techniques.

${ }^{31}$ M.W. Frame, The challenges of intercultural marriage, p. 219-232.

32 C.L. Crippen, Working with intercultural couples and families.
} 
Financial Issues. No significant differences were found between monocultural couples and intercultural couples when it came to handling financial issues. This is contradictory to previous research which stated that $37 \%$ of intercultural couples indicated that the main problem in their marriage was monetary issues. 33

This could be because the sample seemed to include couples financially comfortable with their lives. Also, the Singaporean wives in the sample were different from the Filipino wives in Jabar's ${ }^{34}$ study who were unable to control their spending that led to lower levels of marital satisfaction.

\section{Conclusion}

The study opens up a new field of research within cross-cultural psychology in Singapore's context with regards to marital satisfaction amongst intercultural couples. The obtained results contribute to the valuable insights into the dynamically changing Singaporean society, which may help plan future social policies. This is because Singapore is a cosmopolitan city, whereby people from other countries may be motivated to migrate to Singapore to settle down and start a family due to the strong foundation of interethnical ties and acceptance in Singapore.

Additionally, the results showed some significant differences between monocultural couples and intercultural couples based on the factors of couple dynamics and family factors. The research provided valuable insights to the marital satisfaction levels of intercultural couples in the Singaporean context.

\section{BIBLIOGRAPHY}

Albrecht T.L., Adelman M.B., Communicating social support: A theoretical perspective, [in:] Communicating Social Support, eds T.L. Albrecht, M.B. Adelman, Sage, Newbury Park, CA 1987.

Bhugra D., De Silva P., Couple therapy across cultures, Sexual and Relationship Therapy, 2000, 15.

Blau P.M., Exchange and power in social life, John Wiley, New York 1967.

Carrasco G., Perceptions of same-race and interracial dating couples on sexuality and relationship variables - doctorate dissertation, Texas Tech University, Texas 2007.

${ }^{33}$ D.H. Olson, J. DeFrain, Marriage and the family: Diversity and strengths, Mountain View CA 2000.

${ }^{34}$ M.A. Jabar, Backgrounds of marriage, p. 43-57. 
Crippen C.L., Working with intercultural couples and families: Exploring cultural dissonance to identify transformative opportunities, 2011. Retrieved from http://counselingoutfitters. com/vistas/vistas11/ Article_21.pdf

Davidson J.R., Schneider L.J., Acceptance of Black-White interracial marriage, The Journal of Intergroup Relations, 1992, 19 (3).

Donovan S., Stress and coping techniques in successful intercultural marriages - unpublished master's thesis, Faculty of the Virginia Polytechnic Institute and State University, Virginia 2004.

Falicov C.J., Cross-cultural marriages, [in:] Clinical handbook of couple therapy, eds N. Jacobson, A. Gurman, Guilford, New York 1995.

Faulkner J., Kich G.K., Assessment and engagement stages in therapy with the interracial family, [in:] Cultural perspectives in family therapy, ed. C.J. Falicov, Aspen Systems, Rockville Md. 1983.

Forna M., Differences that get under the skin: Race problems between black skinned people of different origins, "The Guardian", 1992, July.

Frame M.W., The challenges of intercultural marriage: Strategies for pastoral care, Pastoral Psychology, 2004, 52 (3), p. 219-232. Retrieved from: http://scholar.google.com.sg.

Gaines S.O. Jr., Granrose C.S., Rios D.I., Garcia B.F., Page M.S., Farris K.R., Bledsoe K.L., Patterns of attachment and responses to accommodative dilemmas among interethnic/interracial couples, Journal of Social and Personal Relationships, 1999, 16.

Garcia S.D., Rivera S.M., Perceptions of Hispanic and African-American couples at the friendship or engagement stage of a relationship, Journal of Social and Personal Relationships, 1999, 16.

Heaton T.B., Albrecht S.L., The changing pattern of interracial marriage, Social Biology, 1996, 43.

Hegar R.L., Greif G.L., Parental abduction of children from interracial and cross-cultural marriages, Journal of Comparative Family Studies, 1994, 25.

Jabar M.A., Backgrounds of marriage: Conflict experiences of Filipino wives in intercultural marriages, Graduate Journal of Social Science, 2006, 3 (2).

Killian K.D., Crossing borders: Race, gender, and their intersections in interracial couples, Journal of Feminist Family Therapy, 2001, 13, 1.

Kitivipart L., Communication and interaction styles in Thai-American cross-cultural marriage, Ph.D. Dissertation in Psychology, International University, School of Human Behaviour, San Diego 1987.

Kouri K.M., Lasswell M., Black-White marriages: Social change and intergenerational mobility, Marriage \& Family Review, 1993, 19.

La Taillade J.J., Predictors of satisfaction and resiliency in African American/White interracial relationships - unpublished doctoral dissertation, University of Washington, Seattle 1999.

Lewis R. Jr., Yancey G., Bletzer S.S., Racial and nonracial factors that influence spouse choice in Black/White marriages, Journal of Black Studies, 1997, 28.

Mills J.K., Daly J., Longmore A., Kilbride G., A note on family acceptance involving interracial friendships and romantic relationships, Journal of Psychology, 1995, 129.

National Population Secretariat, Prime Minister's Office, Singapore Department of Statistics, Youth \& Sports Ministry of Community Development, Ministry of Home Affairs, and Immigration \& Checkpoints Authority, "Population in brief 2010", Singapore 2010. 
Olson D.H., DeFrain J., Marriage and the family: Diversity and strengths, Mayfield, Mountain View CA 2000.

Sechrest L., Fay T.L., Zaidi S.M., Problem of translation in cross-cultural communication, [in:] Intercultural Communication: A Reader (5th edition), eds L.A. Samovar, R.E. Porter, Wadsworth, Belmont CA 1988.

Shibazaki K., Brennan K.A., When birds of different feathers flock together: A preliminary comparison of intra-ethnic and inter-ethnic dating relationships, Journal of Social and Personal Relationships, 1998, 15.

Shute C., Spitzberg B., Intercultural couples: examining the role of social support, A paper presented to the Hawaii International Conference on Social Sciences, June 12-15, 2003.

Sung B.L., Chinese American intermarriage, Journal of Comparative Family Studies, 1990, 21.

Tan D.W., No mixed feelings over mixed marriages, "The Straits Times", 2010, January 31. Retrieved from: http://www.singaporeunited.sg/cep/index.php/web/News-Room/ No-mixed-feelings-over-mixed-marriages

Taweekuakulkit N., Thai-North American intercultural marriage in the U.S.: A qualitative study of conflict from Thai wives' perspectives - Master's thesis, Wayne State University 2005, Dissertation Abstracts International, Volume: 66-11, Section: A, page: 3866.

Yancey G.A., Yancey S.W., Black-White differences in the use of personal advertisements for individuals seeking interracial relationships, Journal of Black Studies, 1997, 27.

Yancey G.A., Yancey S.W., Interracial dating: Evidence from personal advertisements, Journal of Family Issues, 1998, 19.

Yearbook of Statistics Singapore, 2011. Retrieved from: http://www.singstat.gov.sg/ pubn/reference/yos11/yos2011.pdf. 